\title{
Role of a cyanobacterial cover on structural stability of sandy soils in the Sahelian part of western Niger
}

\author{
O. Malam Issa ${ }^{a}$, Y. Le Bissonnais ${ }^{a}, C$. Défarge ${ }^{b}$ and J. Trichet $^{b}$ \\ a INRA, Unité de Science du Sol-SESCPF, Centre de Recherche d'Orléans, Avenue \\ de la Pomme de Pin, 45160 Ardon, France \\ b UMR 6531 C.N.R.S., Université d'Orléans, B.P. 6759, 45067 Orléans cedex 2, \\ France
}

\section{Abstract}

Microbiotic soil crusts, mostly formed by cyanobacteria, are widespread on the surface of fallow land in western Niger. They lie adjacent to completely bare soils. We have investigated the structural stability of these soils by testing aggregate breakdown under fast-wetting, slow-wetting and mechanical breakdown. The tests were effected on aggregates ranging from 3 to $5 \mathrm{~mm}$ in size. These experiments were completed by micromorphological examinations under light and scanning electron microscope.

For all tests, the fragment size distribution and the mean weight diameter (MWD) revealed the great stability of aggregates from soils with a cyanobacterial cover (MWD 1.82 to $3.10 \mathrm{~mm}$ ), compared to those from soils devoid of cyanobacterial cover (MWD 0.25 to $1.26 \mathrm{~mm}$ ). Fast- and slow-wetting of microbiotic soil crust material induced a lesser disaggregation of aggregates compared to mechanical breakdown. On the contrary, fast-wetting and mechanical breakdown of aggregates from soils devoid of cyanobacterial cover induced a greater disaggregation than slowwetting.

Microscopic examination of microbiotic crusts revealed an intricate network of filamentous cyanobacteria and extracellular polymer secretions, which binds and entraps mineral particles on the soil surface. Organo-mineral aggregates ranging from 0.10 to $0.12 \mathrm{~mm}$ were observed. Below the superficial crusts, filaments and residual organic matter bind tightly soil particles, thus giving a compact structure. The great stability of aggregates of soil with cyanobacterial cover is likely related to the binding and gluing effect of cyanobacteria and derived organic matter. This is consistent with the positive correlation between MWD values and organic carbon content. The present results thereby confirm the resistance to erosion of soil with microbial cover as indicated by field measurements.

Author Keywords: Crusts; Cyanobacteria; Aggregates; Structural stability; Niger; Sahel 


\section{Introduction}

Structural stability of soil is an essential parameter, influencing many soil physical properties such as water infiltration, erodibility, and plant growth (Lynch and Bragg, 1985). It supposes that soil aggregates must be strong enough to withstand the breakdown by physical and physico-chemical mechanisms which take place for example during rainfall events.

In a review, Le Bissonnais (1996) distinguished four main physical and physicochemical mechanisms inducing the breakdown of aggregates: (i) slaking caused by the compression of air entrapped within aggregates during wetting, (ii) breakdown by differential swelling related to the behaviour of clay material after wetting, (iii) breakdown by raindrop impact, and (iv) physico-chemical dispersion due to osmotic stress.

Several methods have been used to assess soil structural stability, the majority consisted in testing aggregate breakdown under varying wetting conditions and energy levels. Results obtained show that structural stability is mainly controlled by the soil organic material, iron and aluminum oxides, and clay contents (Tisdall and Le).

The present study concerns the structural stability of soils of fallow lands in the western part of Niger (Sahel, West Africa). The soil surface comprised completely bare areas lying adjacent to areas covered by microbiotic crust, i.e. microbial communities dominated by filamentous cyanobacteria, turned into a hard crust-like structure because of the severely desiccated conditions in which they thrive. Both field observations and experiments on these soils showed that during rainfall events, areas covered with dense microbiotic crusts are less eroded compared to bare soil (Malam Issa et al., 1998). This is a confirmation of previous works which have ascribed to microbiotic soil crusts a prominent role in stabilisation and preservation against water and wind erosion (Bond; Harper; Kleiner; Campbell; West; Eldridge; Mckenna; Eldridge and P).

Microbiotic crusts also fulfill several other roles, mostly through the physiological activities of cyanobacteria. For example, as primary producers they contribute to the enrichment of soil with organic matter and to the improvement of biological activity (Lange and Lange). Some cyanobacteria fix atmospheric nitrogen, enriching soil with bound nitrogen and hence serve as natural fertilisers (Isichei; Jeffries; Zaady and Malam). In addition, cyanobacteria secrete extracellular polymeric substances (EPS), including capsular polymeric secretions which contribute to the sheath composition, and extracellular polymeric secretions freely secreted in the medium (Stal, 1995). EPS are dominantly formed of polysaccharides and play a major role in the protection of organisms against environmental conditions. For example, they may serve as a medium for water storage and prolong the period during which the organisms can be metabolically active after being rewetted (De Winder, 1990). They also serve in the gliding motility of organisms, or on the contrary in their adhesion to substrates (Stal, 1995). Basically, EPS ensure the survival of cyanobacteria and hence, contribute to the development of microbiotic crusts in severe environmental conditions. Moreover, extracellular polymeric substances secreted by cyanobacteria are recognised as agents of soil particle aggregation (Bond; Danin; Belnap and Eldridge). 
The aim of this work is to assess the structural stability of sand soil covered with microbiotic crust relative to adjacent soils which are devoid of microbiotic crusts. The results are discussed in the light of microscopic observations.

\section{Site descriptions, materials and methods}

\subsection{Site description-material sampling}

The study sites lie at about $13^{\circ} 32$ ' $\mathrm{N}$ and $2^{\circ} 42^{\prime} \mathrm{E}$ on fallow lands near Banizoumbou, about $70 \mathrm{~km}$ northeast of Niamey, the capital city of Niger (Malam and Malam). They varied in their age and microbial cover, thus three types were distinguished: (1) four sites with dense microbiotic cover. They occupied a land that lied fallow for 4 years. Microbial cover, estimated in the field on a $1-\mathrm{m}^{2}$ plot, ranged from $75 \%$ to $85 \%$ of the surface; (2) three sites with moderate microbiotic cover. They occupied a land fallow for 1 year. Microbial cover ranged from $1 \%$ to $30 \%$ of the surface; (3) one bare site, devoid of any microbial cover. This site lied on a land fallow for 1 year.

All the sites are located on residual aeolian sand dunes. The main physical and chemical properties of the soil samples are presented in Table 1. All the samples had a similar texture, sandy to sandy loam soil, with a clay content of less than $5 \%$ and a silt content of less than $21 \%$ (Table 1). The total organic carbon (TOC) content of samples with a microbial cover ranged between 4.2 and $9.1 \mathrm{mg} / \mathrm{g}$ at the surface vs. 1.4 and $3.6 \mathrm{mg} / \mathrm{g}$ at depth (Table 1). The TOC content of surface samples from the bare site was about $1.8 \mathrm{mg} / \mathrm{g}$ (Table 1). The proportion of polysaccharides represents $9-32 \%$ of the TOC content of superficial samples vs. $5-9 \%$ for deep and bare samples (Table 1).

Table 1. Particle-size distribution, total organic carbon and sugar contents of the soil

\begin{tabular}{|c|c|c|c|c|c|c|c|c|}
\hline \multicolumn{3}{|l|}{ Sites } & \multirow{2}{*}{$\begin{array}{l}\text { Depth } \\
(\mathrm{mm})\end{array}$} & \multicolumn{3}{|c|}{ Particle-size distribution } & \multirow{2}{*}{$\begin{array}{l}\text { Total } \\
\text { organic } \\
\text { carbon } \\
(\mathrm{mg} / \mathrm{g}) \\
\end{array}$} & \multirow{2}{*}{$\begin{array}{l}\text { Sugar } \\
\text { content } \\
(\% \text { TOC })\end{array}$} \\
\hline Types & Replicates & & & $\begin{array}{l}\text { Sand } \\
(\%)\end{array}$ & $\begin{array}{l}\text { Silt } \\
(\%)\end{array}$ & $\begin{array}{l}\text { Clay } \\
(\%)\end{array}$ & & \\
\hline \multirow{8}{*}{$\begin{array}{l}\text { Sites with } \\
\text { dense } \\
\text { cyanobacterial } \\
\text { cover }\end{array}$} & J1 & crust & $0-3$ & 83.1 & 12.4 & 2.3 & 6.5 & 32.0 \\
\hline & & $\begin{array}{l}\text { under-crust } \\
\text { material }\end{array}$ & $3-24$ & 93.1 & 2.5 & 2.6 & 1.6 & - \\
\hline & $\mathrm{J} 2$ & crust & $0-3$ & 76.5 & 15.5 & 1.2 & 9.1 & 28.0 \\
\hline & & $\begin{array}{l}\text { under-crust } \\
\text { material }\end{array}$ & $3-23$ & 83.3 & 12.0 & 3.2 & 1.9 & 5.0 \\
\hline & $\mathrm{J} 3$ & crust & $0-7$ & 76.0 & 20.9 & 0.6 & 8.4 & 32.0 \\
\hline & & $\begin{array}{l}\text { under-crust } \\
\text { material }\end{array}$ & $7-23$ & - & - & - & 1.6 & - \\
\hline & $\mathrm{MI} 2$ & crust & $0-3$ & - & - & - & 7.9 & 9.0 \\
\hline & & $\begin{array}{l}\text { under-crust } \\
\text { material }\end{array}$ & $3-33$ & - & - & - & 1.4 & 5.0 \\
\hline \multirow{6}{*}{$\begin{array}{l}\text { Sites with } \\
\text { moderate } \\
\text { cyanobacterial } \\
\text { cover }\end{array}$} & A1 & crust & $0-3$ & 84.8 & 12.4 & 0.6 & 6.1 & 20.0 \\
\hline & & $\begin{array}{l}\text { under-crust } \\
\text { material }\end{array}$ & $3-27$ & 91.8 & 4.6 & 2.0 & 2.4 & - \\
\hline & A2 & crust & $0-3$ & 77.1 & 17.8 & 3.1 & 7.6 & 9.0 \\
\hline & & $\begin{array}{l}\text { under-crust } \\
\text { material }\end{array}$ & $3-28$ & - & - & - & 3.6 & - \\
\hline & $\mathrm{A} 3$ & crust & $0-3$ & 73.6 & 16.4 & 3.0 & 4.2 & 13.0 \\
\hline & & $\begin{array}{l}\text { under-crust } \\
\text { material }\end{array}$ & $3-23$ & - & - & - & 1.5 & 7.0 \\
\hline Bare soil & $\mathrm{Z1}$ & & $0-3$ & 94.7 & 4.8 & 4.7 & 1.8 & 9.0 \\
\hline
\end{tabular}


For surface microscopic observations, pieces of microbiotic crusts were carefully removed, thanks to the polygonal cracking occurring naturally at the surface of the soil when microbiotic crusts wet and get dry. Duplicate samples of soil, approximately $7 \mathrm{~cm}$ thick, were collected from each of the eight sites; one set was impregnated and used to make thin sections and the other set was used for measurements of aggregate stability. Samples for aggregate stability measurement were divided into two subsamples. The first subsample was the superficial layer, ca. 2-5 $\mathrm{mm}$ thick, which comprised the living cyanobacteria of the crusts, whereas the second subsample comprised the crust-underlying material devoid of any living cyanobacteria.

\subsection{Methods}

\subsubsection{Stability measurements}

Stability measurements were carried using Le Bissonnais (1996) method. Aggregates of $3-5 \mathrm{~mm}$ in size obtained by sieving material of crusts, underlying-crust horizons and bare soil were selected. Before measurements aggregates were oven-dried at $40^{\circ} \mathrm{C}$ for $24 \mathrm{~h}$.

The method determines stability of aggregates by using a combination of three treatments, each corresponding to different wetting conditions and energy inputs: fast-wetting, slow-wetting and mechanical breakdown (Attou et al., 1998).

For fast-wetting, a 5-g subsample of dried aggregates was gently immersed in $50 \mathrm{ml}$ of deionized water. After $10 \mathrm{~min}$, the water was removed by a pipette, then residual aggregates were collected.

For slow-wetting, a 5-g subsample of dried aggregates was put on a filter paper and then wetted by capillarity on a suction table at a potential of $-0.3 \mathrm{kPa}$. After $30 \mathrm{~min}$, residual aggregates were collected.

For mechanical breakdown, a 5-g subsample immersed first in ethanol for $10 \mathrm{~min}$ was placed in a flask with $50 \mathrm{ml}$ of deionized water. After obtaining a final volume of $250 \mathrm{ml}$ by adding water, aggregates were rotated end-over-end 10 times. The solution was allowed to settle for 30 min after which the excess water and suspended particles were removed by pipette and the residual material collected.

After each treatment, the residual aggregates were transferred to a sieve with a mesh of $50 \mu \mathrm{m}$ immersed in ethanol, and the particle-size distribution of the resulting material was determined by a combination of wet- and dry-sieving. Wet-sieving was obtained by moving five times, with a Henin apparatus, the $50-\mu \mathrm{m}$ sieve immersed in ethanol. The fraction $<50 \mu \mathrm{m}$ was oven-dried at $105^{\circ} \mathrm{C}$ for $48 \mathrm{~h}$, then weighed. The fraction $>50 \mu \mathrm{m}$ was collected and oven-dried at $105^{\circ} \mathrm{C}$ for $48 \mathrm{~h}$, and then dry-sieved on a column of six sieves with mesh sizes of $2,1,0.5,0.2,0.1$ and $0.05 \mathrm{~mm}$. Weight of aggregates collected on each sieve was determined and expressed as the percentage by dry mass of the samples. 
Aggregate stability was expressed by the resulting fragment size distribution in seven granulometric classes, and by the value of the mean weight diameter (MWD) calculated by the following formula:

$$
\mathrm{MWD}=\frac{\sum_{1}^{7} \overline{x_{i}} w_{i}}{100}
$$

with $\overline{x_{i}}$ being the mean intersieve size and $w_{i}$ the percentage of particles left on each sieve.

\subsubsection{Microbiotic soil crust structures}

Observations of the soil surface were performed on a JEOL JSM 6400 Scanning Electron Microscope (SEM). Samples were coated with gold-palladium and then observed using secondary electron emission. Vertical thin sections were examined on a Leitz Orthoplan light microscope.

\subsubsection{Particle-size distribution-total organic carbon and sugars content}

Particle-size distributions were determined by dry sieving of sand particles and sedimentation of finer particles (pipette method), after the removal of organic matter by hydrogen peroxide $\left(\mathrm{H}_{2} \mathrm{O}_{2}\right)$. Total organic carbon (TOC) was measured with a CNS-2000 Leco analyser. Sugars were extracted with $0.6 \mathrm{M} \mathrm{H}_{2} \mathrm{SO}_{4}$ at $100^{\circ} \mathrm{C}$ for $3 \mathrm{~h}$, and then measured by gas chromatography using a CPG Perkin-Elmer autosystem $\mathrm{XL}$, equipped with FID detector and a 30-m, 0.32-mm column (DB5).

\section{Results}

\subsection{Fragment size distribution}

Fig. $1 A$ and $B$ show the fragment size distributions after the three treatments, for a bare horizon sample, a crust sample and the crust-underlying horizon samples from lands that lied fallow for 4 years (Fig. 1A), and 1 year (Fig. 1B). Regardless of the fallow length, there is a marked difference between samples of crust horizons (samples with cyanobacterial cover), and samples of bare and crust-underlying horizons (devoid of cyanobacterial cover). Samples of crusts are less disaggregated compared to samples of the bare site and crust-underlying horizons (Fig. 1A,B). Fragments of crusts collected after all treatments mainly occurred within the $>2-\mathrm{mm}$ size range, whereas the bulk fragments obtained from crust-underlying and the bare site samples occurred in the $0.1-0.5-\mathrm{mm}$ size range (Fig. $1 \mathrm{~A}, \mathrm{~B}$ ). 

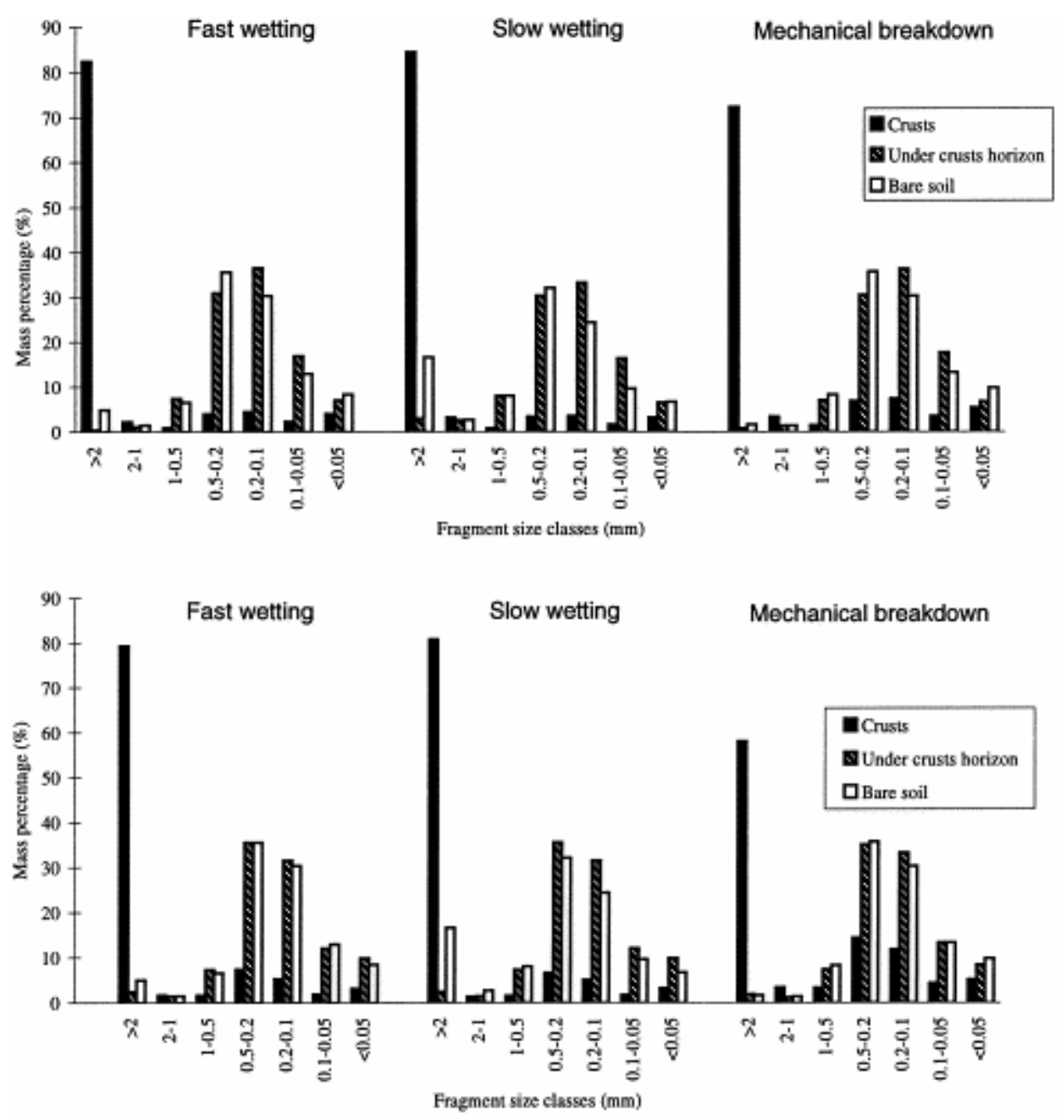

Fig. 1. Fragment size distributions of soil aggregates after the three testing treatments. (A) Comparison between soil with a dense cyanobacterial cover (crust) from a 4-year fallow land, the underlying horizon of the same crust, and the bare soil. (B) Comparison between a soil with a moderate cyanobacterial cover (crust) from a 1-year fallow land, the underlying horizon of the same crust, and the bare soil.

In addition, the behaviour of crust samples with regard to the three treatments differed significantly. Fast- and slow-wetting of crust material induced less disaggregation than did mechanical breakdown. After fast- and slow-wetting of crust material, the proportions of aggregates $>2 \mathrm{~mm}$ ranged, respectively between $61 \%$ and $88 \%, 65 \%$ and $86 \%$ vs. just $47 \%$ and $77 \%$ obtained after mechanical breakdown (Fig. 1A,B).

Fragments of samples devoid of cyanobacterial cover exhibited a completely different behaviour, as the greatest disaggregation was induced by fast-wetting and mechanical breakdown. Among collected fragments, aggregates $>2 \mathrm{~mm}$ represented only $0-8 \%$ and $1-3 \%$ after fast-wetting and mechanical breakdown, respectively, vs. $2-29 \%$ for slow-wetting.

Fragment size distribution showed a significant difference in aggregate stability between samples densely covered by cyanobacteria, i.e. samples from 4-year fallow lands (Fig. 1A), and soil moderately covered by cyanobacteria, i.e. samples from 1- 
year fallow lands (Fig. 1B). Crust samples with dense cyanobacterial cover showed greater aggregate stability than those with moderate cyanobacterial cover. Collected materials after treatments of the first contained in average $70 \%$ of $>2-\mathrm{mm}$ aggregates whereas only $54 \%$ resulted after treatments of the latter (compare A and B, Fig. 1).

\subsection{Mean weight diameter (MWD)}

MWD of the samples reflected the results indicated by fragment size distributions. For crust samples, MWD ranged in average between 2.28-3.10, 2.40-3.06 and 1.82-3.03 mm, respectively, after fast- and slow-wetting and mechanical breakdown (Table 2). In contrast, samples devoid of cyanobacterial cover (samples of the bare site and crust-underlying materials) ranged in average MWD between 0.25-0.56, $0.33-1.26$ and $0.26-0.38 \mathrm{~mm}$, respectively, after fast- and slow-wetting and mechanical breakdown (Table 2). The multiple comparison test (Tukey) showed that MWD of samples devoid of cyanobacterial cover (samples of the bare site and crustunderlying materials) were not significantly different $(p=0.05)$ after all the treatments (Table 3). On the contrary MWD of samples devoid of cyanobacterial cover were significantly different $(p=0.05)$ from those of crust samples (Table 3$)$. The MWD values reflect the positive effect of microbial cover on soil aggregate stability.

Table 2. Mean weight diameter (MWD) of soil aggregates after the three treatments (mean values of three replicates)

\begin{tabular}{|c|c|c|c|c|c|c|}
\hline \multicolumn{3}{|l|}{ Samples } & \multicolumn{4}{|c|}{ Mean weight diameter (MWD, mm) } \\
\hline Sample types & Sites & References & $\begin{array}{l}\text { Fast- } \\
\text { wetting }\end{array}$ & $\begin{array}{l}\text { Slow- } \\
\text { wetting }\end{array}$ & $\begin{array}{l}\text { Mechanical } \\
\text { breakdown }\end{array}$ & Mean values \\
\hline \multirow[t]{7}{*}{ Crusts } & \multirow{4}{*}{$\begin{array}{l}\text { Sites with dense } \\
\text { cyanobacterial cover }\end{array}$} & $\mathrm{J} 1$ & 2.94 & 2.63 & 3.03 & 2.86 \\
\hline & & $\mathrm{J} 2$ & 2.72 & 2.74 & 2.27 & 2.58 \\
\hline & & $\mathrm{J} 3$ & 2.82 & 2.84 & 2.49 & 2.71 \\
\hline & & ML2 & 3.10 & 3.06 & 2.76 & 2.97 \\
\hline & \multirow{3}{*}{$\begin{array}{l}\text { Sites with moderate } \\
\text { cyanobacterial cover }\end{array}$} & A1 & 2.85 & 2.89 & 2.18 & 2.64 \\
\hline & & A2 & 2.39 & 2.40 & 2.09 & 2.29 \\
\hline & & A3 & 2.28 & 2.45 & 1.82 & 2.18 \\
\hline \multirow{7}{*}{$\begin{array}{l}\text { Under-crust } \\
\text { horizons }\end{array}$} & \multirow{4}{*}{$\begin{array}{l}\text { Sites with dense } \\
\text { cyanobacterial cover }\end{array}$} & J1 & 0.26 & 0.37 & 0.27 & 0.30 \\
\hline & & $\mathrm{J} 2$ & 0.28 & 0.48 & 0.27 & 0.34 \\
\hline & & $\mathrm{J} 3$ & 0.25 & 0.33 & 0.33 & 0.30 \\
\hline & & ML2 & 0.37 & 0.50 & 0.26 & 0.37 \\
\hline & \multirow{3}{*}{$\begin{array}{l}\text { Sites with moderate } \\
\text { cyanobacterial cover }\end{array}$} & A1 & 0.34 & 0.58 & 0.32 & 0.41 \\
\hline & & A2 & 0.56 & 1.26 & 0.38 & 0.73 \\
\hline & & A3 & 0.33 & 0.69 & 0.31 & 0.44 \\
\hline \multicolumn{2}{|l|}{ Bare soil } & $\mathrm{Z} 1$ & 0.42 & 0.84 & 0.32 & 0.53 \\
\hline
\end{tabular}


Table 3. Multiple comparison test (95\% Tukey HSD) of MWD values after all treatments (fast-wetting, slow-wetting and mechanical breakdown)

\begin{tabular}{lcllll}
\hline & Level & Count & LS mean & Homogeneous & Groups \\
\hline Crust & 1 & 62 & 2.6042097 & $\mathrm{x}$ & $\mathrm{x}$ \\
Under-crust material & 2 & 63 & 0.4169683 & & $\mathrm{x}$ \\
Bare soil & 3 & 9 & 0.5265556 & & \\
& & & & \\
Contrast & Difference \pm & Limits & & \\
\hline $1-2$ & 2.18724 & $0.12504^{*}$ & & \\
$1-3$ & 2.07765 & $0.24933^{*}$ & & \\
$2-3$ & -0.10959 & 0.24908 & & & \\
\hline
\end{tabular}

- Denotes a statistically significant difference.

Fig. 2 shows the relationship between the MWD values and the TOC content of the samples (Malam Issa, 1999). Significant coefficients of linear regression $\left(r^{2}\right.$ ranging between 0.78 and $0.83 ; p<0.001$ ) were found between the MWD values and the TOC content of samples (Fig. 2A-D). In contrast, linear regressions between the MWD values and the sugar content of samples exhibit no significant coefficient of linear regression, even tough both the MWD values and the sugar content increased with increasing degree of microbial cover (Table 1 and Table 2).

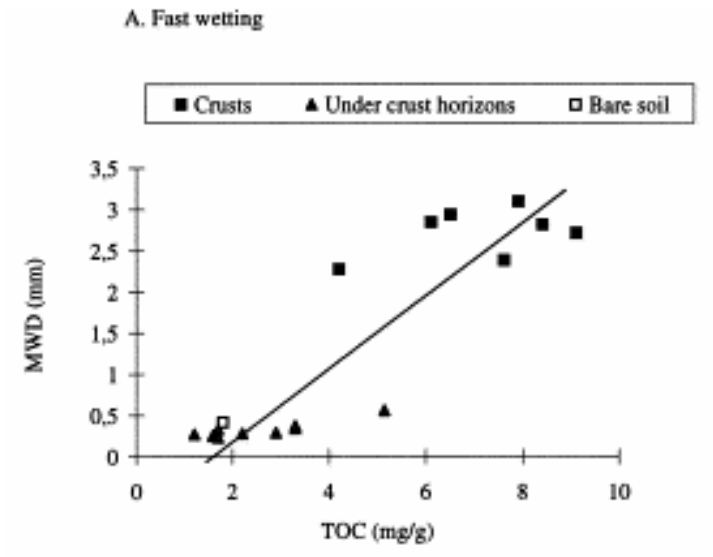

C. Mechanichal breakdown

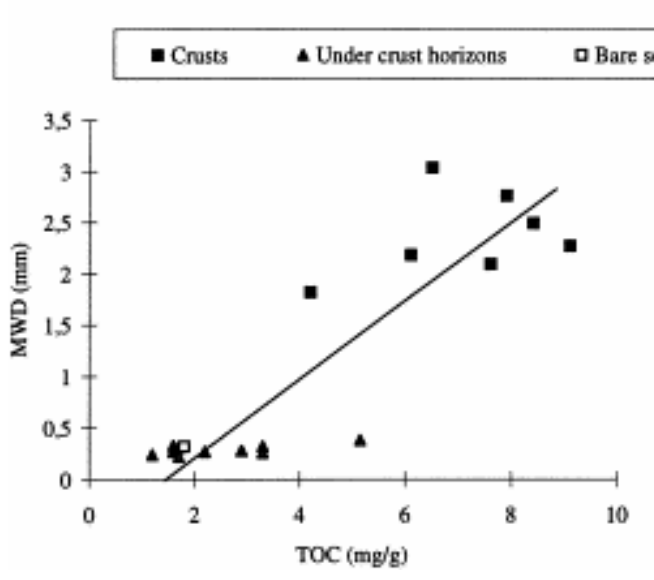

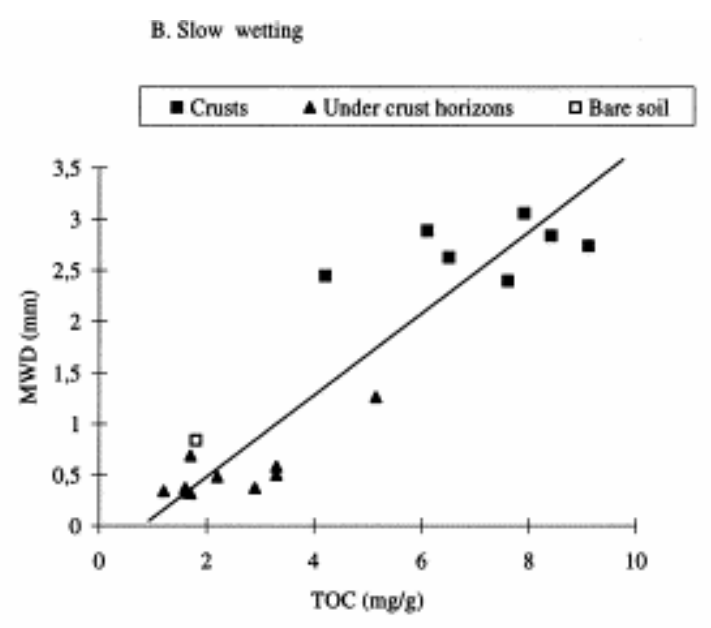

D. Mean values of the three treatments

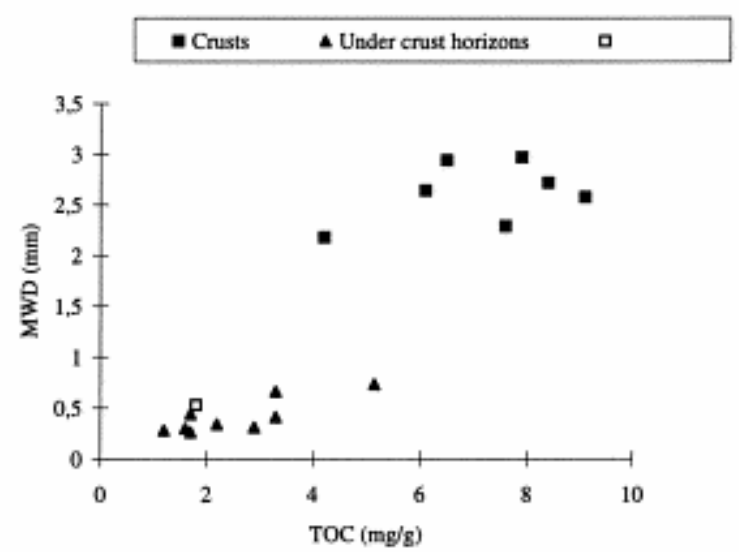


Fig. 2. Relationships between total organic carbon content (TOC) of soils and values of mean weight diameter (MWD) obtained after the three treatments. (A) After fast-wetting treatment $\left(r^{2}=0.80\right)$. (B) After slow-wetting treatment $\left(r^{2}=0.83\right)$. (C) After mechanical breakdown treatment $\left(r^{2}=0.78\right)$. (D) Mean values of MWD of the three treatments $\left(r^{2}=0.82\right)$.

\subsection{Surface observations}

The surface of the bare samples is composed essentially of rounded quartz grains with rare fine particles, whereas the surface of samples with cyanobacterial cover showed a surface network of cyanobacterial filaments 10-16 $\mu \mathrm{m}$ in diameter (Fig. $3 A)$. In some places, the network also consists of organic membranes which are probably derived from extracellular polymer substances (eps, Fig. 3B). Sand and coarse silt particles were trapped in this network (S, Fig. 3A,C), whereas finer particles stick on the surface of filaments (Fig. 3A) and organic membranes (Fig. 3B). Organo-mineral aggregates of $100-120 \mu \mathrm{m}$ in diameter, composed of fine mineral particles $(<10 \mu \mathrm{m})$, filaments and organic membranes, can also be observed at the surface of some crusts (arrows, Fig. 3C,D).
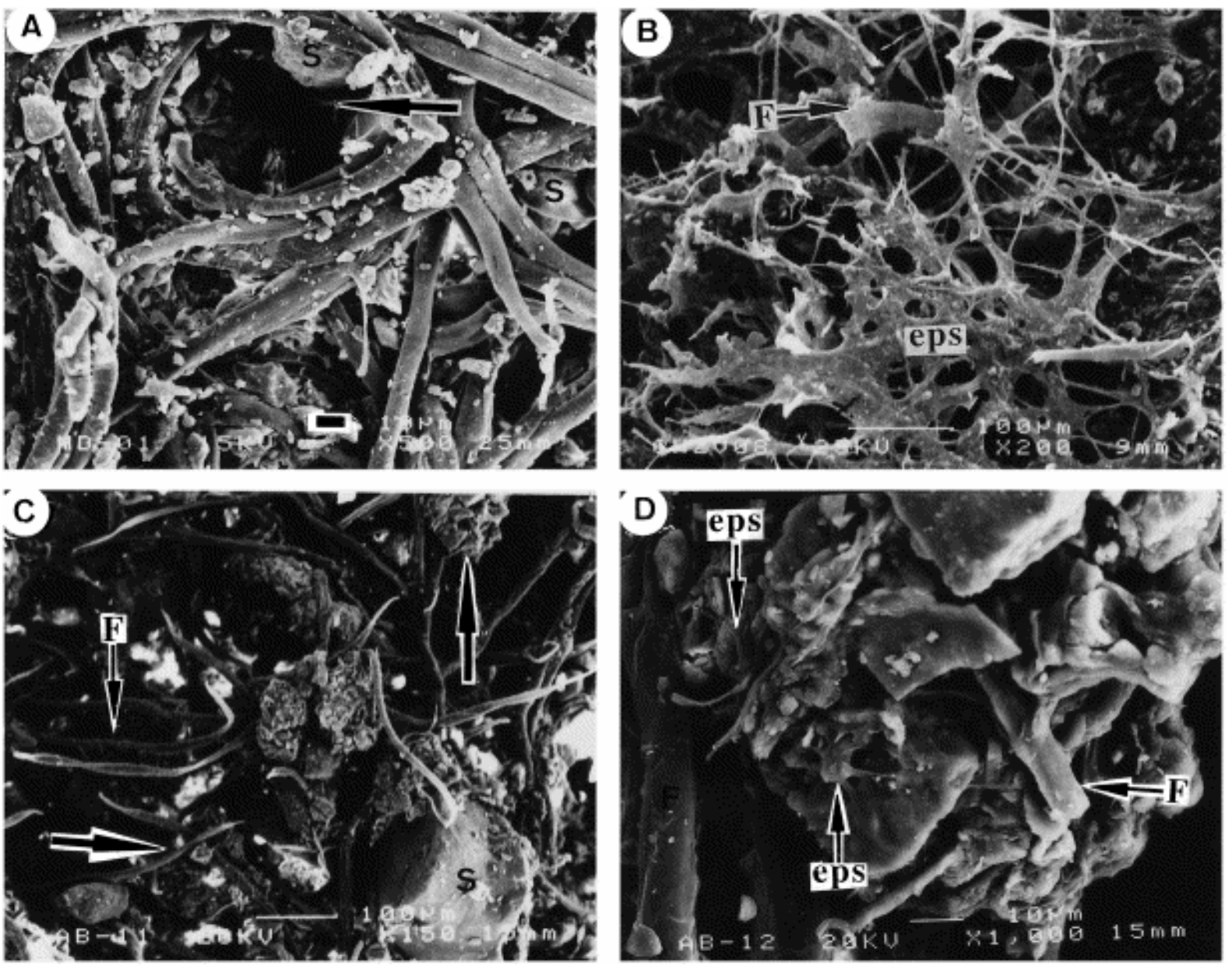

Fig. 3. SEM micrographs of the soil surface. (A) View showing the superficial network of cyanobacterial filaments. Note coarse sand and silt (S) trapped in the network, fine particles sticking on filament surfaces, and superficial pores of 25-60 $\mu \mathrm{m}$ in diameter formed by the intertwining of filaments (arrow). (B) Organic membrane, formed of extracellular polysaccharide secretions (eps), associated with filament $(F)$ network. (C) Filament network and organo-mineral aggregates 100-120 $\mu \mathrm{m}$ in diameter (arrows). (D) Blow up of an organo-mineral aggregate in (C), exhibiting filaments (F), eps and mineral particles. 


\subsection{Profile observations}

Profiles of soils with a moderate cyanobacterial cover showed a superficial layer, 5 $\mathrm{mm}$ thick, formed of sand and coarse silt particles tightly packed, and a lower layer of mixed particles (mostly sandy) loosely packed (Fig. 4A,B). A thin lamina of living filamentous micro-organisms associated with fine particles was observed at the top of the surface layer (arrows, Fig. 4A). Pores were partially clogged by fine particles (V, Fig. 4A). The underlying material consists of fine particles forming bridges between sand particles (Q, Fig. 4A), small aggregates (A, Fig. 4A) and well-interconnected packing pores (V, Fig. 4B).
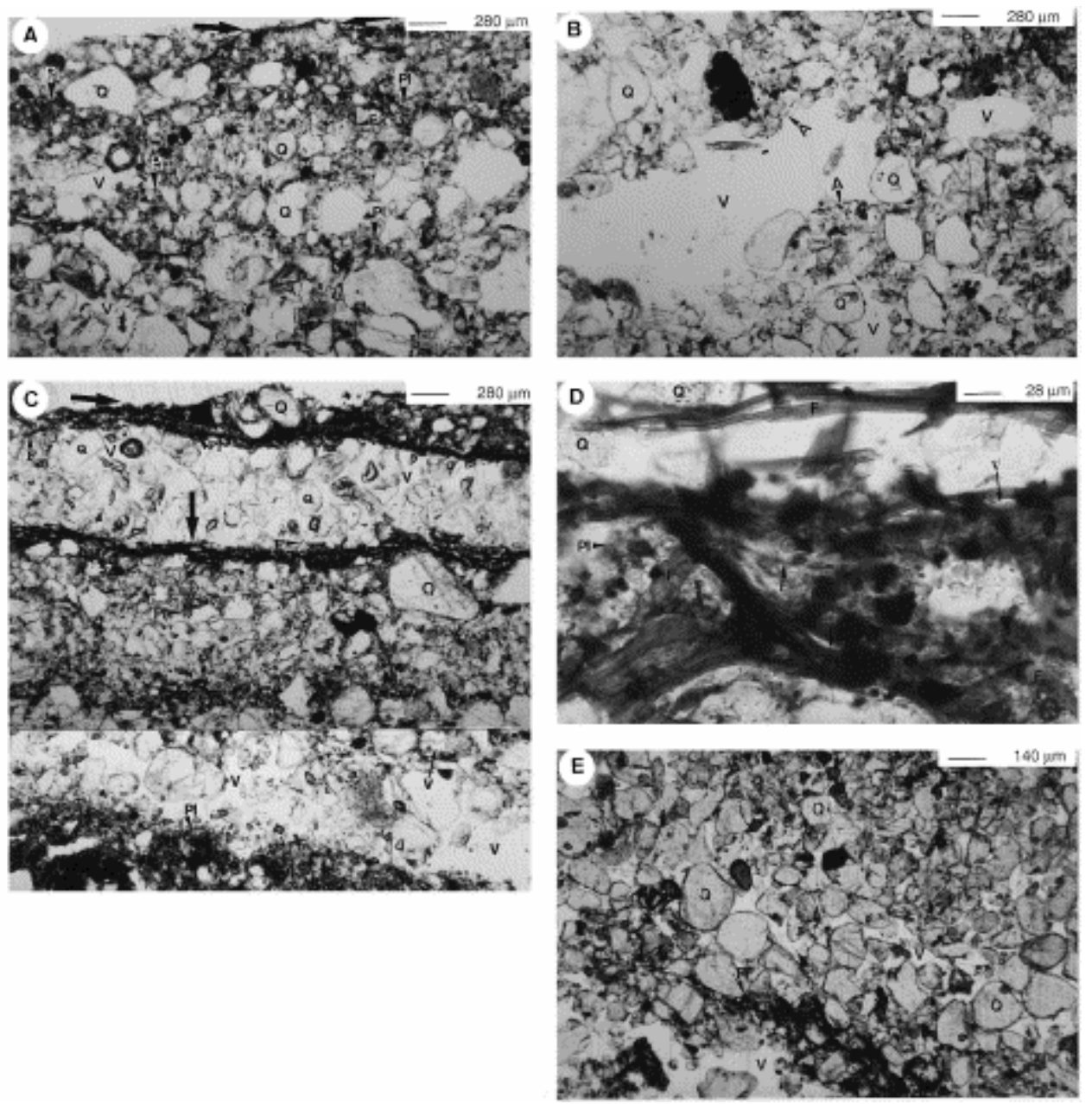

Fig. 4. Photomicrographs of vertical thin sections of studied soils. (a-b) Soil with moderate cyanobacterial cover. (A) Superficial layer of the profile with discontinuous layer of living microorganisms (arrows). Note the close fabric formed of coarse to medium sand grains $(Q)$, fine mineral particles (PI) and non-connected polyconcave pores $(\mathrm{V})$. Rare filaments $(\mathrm{F})$ are observed at depth. $(\mathrm{B})$ Crust underlying material showing a loose fabric, including connected pores $(\mathrm{V})$ and small aggregates (A). (c-e) Soil with dense microbial cover. (C) Superficial part of the soil profile showing alternation of well-sorted sand layers and layers of mixed particles. Laminae of living micro-organisms (arrows) are associated with layers of mixed particles. Note the strong association between filaments $(F)$, fine particles (PI) and coarse sand grains $(\mathrm{Q})$ among the superficial layer. (D) Enlarged view of the layer containing living micro-organisms. (E) Underlying material of the crusts, formed of coarse sand grains $(\mathrm{Q})$ and few fine particles $(\mathrm{PI})$, showing a loose fabric with well inter-connected pores $(\mathrm{V})$. 
Profiles of soil with a dense cyanobacterial cover showed two different layers (Fig. 4C): a surface layer, $5 \mathrm{~mm}$ thick, composed of mixed material sublayers, alternating with sublayers of well-sorted, aeolian-borne sand, and an underlying layer, several centimetres thick, formed essentially of sand particles. Mixed material of the top layer comprised cyanobacterial horizons of 50-100 $\mu \mathrm{m}$ thick formed by filaments associated with fine particles (arrows, Fig. 4C). The profile exhibited three of such cyanobacterial horizons buried by the aeolian-borne sand sublayers. Filaments also grew among sand sublayers in the grains interspace (F, Fig. 4D). Pores were rounded to vesicular (V, Fig. 4C,D) because of compaction and infilling by fine particles (PI, Fig. 4C,D). The lower part of the profile comprised fine particles in intergrain spaces and showed a loose fabric compared to the superficial layer (compare Fig. 4C and E). Pores were tubular and interconnected (V, Fig. 4E).

\section{Discussion and conclusions}

Results of stability measurements reported here, based on the behaviour of soil materials with regard to fast- and slow-wetting or mechanical breakdown, revealed marked differences between soils with cyanobacterial cover and those devoid of cyanobacteria. The proportion of fragments $>2 \mathrm{~mm}$ in size, in soils with cyanobacterial cover (initially $3-5 \mathrm{~mm}$ in diameter), ranged between $47 \%$ and $88 \%$ vs. $0 \%$ and $29 \%$ for soil devoid of cyanobacterial cover. Obviously, soil with a surface cyanobacterial cover was far more stable than soils without cyanobacteria. Values of MWD ranged between 1.82 and $3.10 \mathrm{~mm}$ for samples with cyanobacterial cover vs. 0.25 to $1.26 \mathrm{~mm}$ for samples devoid of cyanobacterial cover. Following Le Bissonnais (1996), samples with cyanobacterial cover can be classified as very stable material, and those devoid of cyanobacterial cover as unstable horizons.

A positive correlation was shown between MWD and TOC (Fig. 2A-D), suggesting that the observed stability of the microbially covered soil may be ascribed to the crust organisms, as they are the main producers of organic material (Malam Issa, 1999). In addition, soils with dense cyanobacterial cover, and a higher TOC content (6.5-9.1 $\mathrm{mg} / \mathrm{g}$ ) exhibit more stable aggregates (MWD 2.58-2.97 $\mathrm{mm}$ vs. $2.18-2.64 \mathrm{~mm}$ ) than soil with a moderate cyanobacterial cover and a lower TOC content (4.2-7.6 mg/g).

Sugar content of soil with microbial cover represents about $9 \%$ to $32 \%$ of its TOC content (Table 1). This is much higher than the sugar content in soil devoid of cyanobacterial cover, where sugar content ranges between $5 \%$ and $9 \%$ of the TOC. Correlation between sugar content of samples and their MWD values shows no significant linear relation. However, with increasing degree of cyanobacterial cover, sugar content increased as MWD values increased also (Table 1). This probably shows the role of mucilaginous excretions and cyanobacterial filaments, both rich in polysaccharides, in causing the high stability of microbially covered samples, found in previous studies (Danin; P and Mckenna) and our own microscopic observations.

Contribution of micro-organisms to soil aggregate stability is a well-known phenomenon. Two major mechanisms are suggested by Lynch and Bragg (1985): the ability of some micro-organisms, mostly filamentous, to mechanically bind soil particles, and the production of binding agents by some others (bacteria). In general, fungi are reported to be the most effective in soil aggregation (Lynch and Bragg, 1985). Our results, as other studies (Danin; Belnap; $P$ and Malam), show that 
cyanobacteria may also be implicated in soil particle aggregation. Cyanobacteria exert a mechanical effect on soil particles by the superficial network of filaments, and function as glue due to the polysaccharide nature of the extracellular substances they secrete. The cyanobacterial network traps sand and coarse silt particles whereas clay and fine silt sized particles adhere to the surfaces of filaments and EPS (Fig. $3 A, B$ and $D)$. This is also observed at depth, where filaments enmesh the particles among which they once grew before they were buried (Fig. 4C,D). As concluded by Malam Issa et al. (1999), this will result in soil accretion through a rhythmic aggradation of horizons, alternately formed of cyanobacteria associated to fine particles and, well-sorted, aeolian-borne sands. In some microbiotic crusts, porous organic bodies (probably resulting from extracellular polymer secretions) occur at depth, thus enhancing the effect of filaments (Malam Issa et al., 1999).

All these mechanisms assume a close and stable association between microorganisms and mineral grains, which leads to the formation of water stable organomineral aggregates (Fig. 3C,D). This is in agreement with other studies (Bond; Bailey and Rogers), which reported aggregation of soil particles by cyanobacteria and green algae. The inoculation of soil surfaces with Nostoc muscorum, a $\mathrm{N}_{2}$-fixing cyanobacteria, may lead to an increase of the aggregates stability by $18 \%$ (Rogers and Mckenna).

Besides their role as binding and gluing agents of soil particles, cyanobacteria materials may also contribute to the aggregate stability through their hydrophobic properties. It is well known that when dry aggregates are wetted, they slake because of entrapped air and differential swelling (Le and Attou), with the degree of slaking greatly dependent on the proportion of hydrophobic material (Jouany and Chenu), the clay content, and silt-clay fabric (Attou et al., 1998). Presence of hydrophobic properties induces a slower release of entrapped air, whereas the clay content and silt-clay fabric control the volume of air within aggregates by affecting the pore size distribution. Thus, a high hydrophobic material or high clay content, accompanied with silt-clay fabric, reduce slaking by entrapped air. Slaking by differential swelling depends largely on the aggregates clay content, as soils with high clay content show more disaggregation by swelling. The microbiotic crusts studied here have a low clay content, but a high content of hydrophobic material (resulting from the protein complex of the cyanobacteria sheath) (Bar and Kidron). Consequently, this results in less breakdown by slaking, as indicated by the behaviour of these crusts after fastand slow-wetting (Fig. 1A,B). The hydrophobic properties of cyanobacterial filaments and derived organic matter prevent quick wetting of crusted soils for at least 5 to 6 min (Kidron et al., 1999), and the low clay content does not induce breakdown by swelling.

The results of this study confirm the role of derived cyanobacterial material (filaments and extracellular secretions) in the formation of water stable aggregates. Cyanobacteria function to bind mineral particle together and reduce aggregate breakdown. This will result in soil particle stabilisation and reduce water and wind erosion (Williams; Belnap and Belnap). Hence, cyanobacteria will reduce loss of essential elements attached to soil fine particles. There is no doubt that the cyanobacterial cover at the surface of fallow lands in the Sahelian part of western Niger improves soil structure and fertility, thus, also may favour subsequent crop production. 


\section{Acknowledgements}

This work formed part of a research programme in West Africa (Projet jachère) funded by EU and IRD (Institut de Recherche et de Développement, formerly ORSTOM). The authors gratefully acknowledge C. Valentin and J.-L. Rajot for help with fieldwork, J.-R. Disnar and N. Lottier for help with sugar analyses, H. Gaillard, C. Le Lay and A. Genty for their skilled technical assistance, and H. Bourennane for help with statistical analyses of the data. Reviews by J. Belnap and F. Pérez significantly improved the paper.

\section{References}

Attou et al., 1998F. Attou, A. Bruand and Y. Le Bissonnais, Effect of clay content and silt-clay fabric on stability of artificial aggregates. European Journal of Soil Science 49 (1998), pp. 569-577.

Bailey et al., 1973D. Bailey, A.P. Mazurak and J.R. Rosowski , Aggregation of soil particles by algae. Journal of Phycology 9 (1973), pp. 99-101.

Bar-Or and Shilo, 1988Y. Bar-Or and M. Shilo, The role of cell-bound flocculants in coflocculation of benthic cyanobacteria with clay particles. FEMS Microbiology Ecology 53 (1988), pp. 169-174.

Belnap and Gardner, 1993J. Belnap and J.S. Gardner, Soil microstructure in soils of the Colorado Plateau: the role of the cyanobacterium Microcoleus vaginatus. Great Basin Naturalist 53 (1993), pp. 40-47.

Belnap and Gillette, 1997J. Belnap and D.A. Gillette, Disturbance of biological soil crusts: impacts on potential wind erodibility of sandy desert soils in southeastern Utah, USA. Land Degradation and Development 8 (1997), pp. 355-362.

Belnap and Gillette, 1998J. Belnap and D.A. Gillette, Vulnerability of desert soil surfaces to wind erosion: impacts of soil texture and disturbance. Journal of Arid Environments 39 (1998), pp. 133-142.

Bond and Harris, 1964R.D. Bond and J.R. Harris, The influence of the microflora on physical properties of soils: I. Effects associated with filamentous algae and fungi. Australian Journal of Soil Research 2 (1964), pp. 111-122.

Campbell, 1979S.E. Campbell, Soil stabilization by prokaryotic desert crust: implications for precambrian land biota. Origin of Life 9 (1979), pp. 335-348.

Chenu et al., 2000C. Chenu, Y. Le Bissonnais and D. Arrouays, Organic matter influence on clay wettability and soil aggregate stability. Soil Science Society of America Journal (2000) (in press) .

Danin et al., 1989A. Danin, Y. Bar-Or, I. Dor and T. Yisraeli, The role of cyanobacteria in stabilization of sand dunes in Southern Israel. Ecologia Mediterranea (1989), pp. 55-64. 
De Winder, 1990De Winder, B., 1990. Ecophysiological strategies of drought-tolerant phototrophic micro-organisms in dune soils, Thesis, University of Amsterdam, The Netherlands, $94 \mathrm{pp}$.

Eldridge and Greene, 1994D.J. Eldridge and R.S.B. Greene, Assessment of sediment yield by splash erosion on a semi-arid soil with varying cryptogam cover. Journal of Arid Environments 26 (1994), pp. 221-232.

Eldridge and Kinell, 1997D.J. Eldridge and P.I.A. Kinell , Assessment of erosion rates from microphytic-dominated calcareous soils under rain-impacted flow. Australian Journal of Soil Research 35 (1997), pp. 475-489.

Harper and Marble, 1988K.T. Harper and J.R. Marble, A role for non vascular plants in management of arid and semiarid rangelands. In: P.T. Tueller, Editor, Vegetation Science Applications for Rangeland Analysis and Management, Kluwer Academic Publishings, London, UK (1988), pp. 135-169.

Isichei, 1980A.O. Isichei, Nitrogen fixation by blue-green algal soil crusts in Nigeria savannah. In: T. Rosswall, Editor, Nitrogen Cycling in West African Ecosystems, SCOPE-UNEP, International Nitrogen Unit, Royal Swedish Academy of Sciences, Stockholm (1980), pp. 191-198.

Jeffries et al., 1992D.L. Jeffries, J.M. Klopatek, S.O. Link and H. Bolton, Jr. , Acetylene reduction by cryptogamic crusts from a blackbrush community as related to resaturation and dehydration. Soil Biology \& Biochemistry 24 (1992), pp. 11011105.

Jouany et al., 1992C. Jouany, C. Chenu and P. Chassin, Détermination de la mouillabilité des constituants du sol à partir de mesures d'angles de contacts: revue bibliographique. Science du Sol 135 (1992), pp. 184-192.

Kidron et al., 1999G.J. Kidron, D.H. Yaalon and A. Vonshak, Two cause for runoff initiation on microbiotic crusts: hydrophobicity and pore clogging. Soil Science 164 (1999), pp. 18-27.

Kleiner and Harper, 1977E.F. Kleiner and K.T. Harper, Soil properties in relation to cryptogamic groundcover in Canyon Lands National Park. Journal of Range Management 30 (1977), pp. 202-205.

Lange et al., 1992O.L. Lange, G.J. Kidron, B. Büdel, A. Meyer, E. Kilian and A. Abeliovich, Taxonomic composition and photosynthetic characteristics of the 'biological soil crusts' covering sand dunes in the western Negev desert. Functional Ecology 6 (1992), pp. 519-527.

Lange et al., 1994O.L. Lange, A. Meyer, H. Zellner and U. Heber, Photosynthesis and water relations of lichen soil crusts: field measurements in the coastal fog zone of the Namib Desert. Functional Ecology 8 (1994), pp. 253-264. 
Le Bissonnais, 1996Y. Le Bissonnais, Aggregate stability and assessment of soil crustability and erodibility: I. Theory and methodology. European Journal of Soil Science 47 (1996), pp. 425-437.

Le Bissonnais and Singer, 1993Y. Le Bissonnais and M.J. Singer, Seal formation, runoff and interrill erosion from seventeen California soils. Soil Science Society of America Journal 57 (1993), pp. 244-249.

Lynch and Bragg, 1985J.M. Lynch and E. Bragg, Microorganisms and aggregate stability. In: Advances in Soil Sciences, Springer-Verlag, New York (1985), pp. 134170.

Malam Issa, 1999Malam Issa, O., 1999. Etude du rôle des croûtes microbiotiques dans les sols de deux écosytèmes sahéliens (jachères et brousse tigrée) au Niger: micromorphologie, propriétés physiques et biogéochimiques. PhD thesis, University of Orléans, p. 277.

Malam Issa et al., 1998O. Malam Issa, J. Trichet, C. Défarge, C. Valentin, J.-L. Rajot and A. Couté , Micromorphology of microbiotic crusts from Niger soils. Influence on soil-water dynamics. In: (1998) 7 pp. .

Malam Issa et al., 19990. Malam Issa, J. Trichet, C. Défarge and C. Valentin , Morphology and microstructure of microbiotic soil crusts on a tiger bush sequence (Niger, Sahel). Catena 37 (1999), pp. 175-196.

Malam Issa et al., 2000O. Malam Issa, J.L. Stal, C. Défarge, A. Couté and J. Trichet, Nitrogen fixation by microbial crusts from desiccated Sahelian soils (Niger). Soil Biology \& Biochemistry (2000) in press .

Mckenna Neuman et al., 1996C.M. Mckenna Neuman, C.D. Maxwell and J.W. Boulton , Wind transport of sand surfaces crusted with photoautotrophic microorganisms. Catena 27 (1996), pp. 229-247.

Pérez, 1997F.L. Pérez, Microbiotic crusts in the high equatorial Andes, and their influence on paramo soil. Catena 31 (1997), pp. 173-198.

Rogers and Burns, 1994S.L. Rogers and R.G. Burns, Changes in aggregate stability, nutrient status, indigenous microbial populations, and seedling emergence, following inoculation of soil with Nostoc muscorum. Biology and Fertility of Soils $\mathbf{1 8}$ (1994), pp. 209-215.

Stal, 1995L.J. Stal, Physiological ecology of cyanobacteria in microbial mats and other communities. New Phytologist 131 (1995), pp. 1-32.

Tisdall and Oades, 1982J.M. Tisdall and J.M. Oades, Organic matter and waterstable aggregates. Journal of Soil Science 33 (1982), pp. 141-163.

West, 1990N.E. West, Structure and function of microphytic soil crusts in wildland ecosystems of arid to semi-arid regions. Advances in Ecological Research 20 (1990), pp. $180-223$. 
Williams et al., 1995J.D. Williams, J.P. Dobrowolski and N.E. West, Microphytic crust influences on interrill erosion and infiltration capacity. Transactions of the American Society of Agricultural Engineers 38 (1995), pp. 139-146.

Zaady et al., 1998E. Zaady, P. Groffman and S. Moshe, Nitrogen fixation in macroand microphytic patches in the Negev Desert. Soil Biology \& Biochemistry 30 (1998), pp. 449-454. 